DOI: 10.46340/eujem.2020.6.3.11

Olena Kudyrko, PhD in Economics

ORCID iD : http://orcid.org/0000-0002-5090-1208

Vinnytsia Institute of Trade and Economics of Kyiv National University

of Trade and Economics, Ukraine

Iryna Krupelnytska, PhD in Economics

ORCID iD : http://orcid.org/0000-0002-2487-3362

Vinnytsia Institute of Trade and Economics of Kyiv National University

of Trade and Economics, Ukraine

Inna Kopchykova, PhD in Economics

ORCID iD : http://orcid.org/0000-0001-7752-1603

Vinnytsia Institute of Trade and Economics of Kyiv National University

of Trade and Economics, Ukraine

\title{
COMMODITIES AS AN OBJECT \\ OF MANAGEMENT OF A RETAIL \\ ENTERPRISE
}

Олена Кудирко, к.е.н.

Ірина Крупельницька, к.е.н.

Інна Копчикова, к.е.н.

Вінницький торговельно-економічний інститут КНTЕУ, Україна

\section{ТОВАРНІ ЗАПАСИ ЯК ОБ'СКТ УПРАВЛІННЯ ПІДПРИСМСТВА РОЗДРІБНОЇ ТОРГІВЛІ}

The article deals with the essence and peculiarities of management by commodity operations as a structural component of the object of the financial cycle of a trading enterprise. The place of commodity transactions in the economic activity of trading enterprises is determined. Theoretical provisions of the development and implementation of the commodity operations management policy are studied. It is substantiated that the central object of commodity transactions is the stock, whose essential characteristics are determined according to the classification groups, which can be attributed to them. Therefore, for the purpose of full disclosure of the economic essence of the commodity of the retail enterprises, their classification has been carried out, which at the same time will allow to significantly expand the characteristics reflecting the essence of the commodity of the retail enterprise.

Keywords: commodity operations, inventories, retail, pharmaceuticals, turnover.

Постановка проблеми. Розвиток торговельної галузі як системи неможливий без участі роздрібної торгівлі, яка виступає в ролі активного учасника споживчого ринку й сполучною ланкою між виробником i споживачем. У сучасних умовах господарювання роздрібна торгівля характеризується все більшим ускладненням структури, обумовленим розширенням масштабів діяльності, ростом обсягу циркулюючих по ії каналах мас товарів, збільшенням числа структурних елементів і різноманіттям їх зв'язків між собою й постачальниками. Усі ці обставини вимагають нових підходів до управління товарними запасами і торговельним підприємством в цілому.

Мета статті. Виявлення особливостей управління товарними запасами підприємств роздрібної торгівлі та обгрунтування шляхів удосконалення торговельних операцій.

Аналіз останніх досліджень і публікацій. Дослідженню питань з управління товарними операціямии в торгівлі присвячено праці багатьох відомих вітчизняних науковців: М.Т. Білуха, Ф.Ф. Бутинець, Б.І. Валуєв, В.П. Завгородній, М.В. Кужельний, В.Д. Лагутін, Л.О. Лігоненко, 
А.А. Мазаракі, С.В. Мних, Н.І. Морозова, Л.В. Нападовська, В.О. Озеран, К.С. Олініченко, Ю.І. Осадчий, М.С. Пушкар, О.Ю. Редько, В.С. Рудницький, В.В. Сопко, Б.Ф. Усач, а також зарубіжних: Х. Андерсен, М.І. Баканов, В.Б. Івашкевич, Б. Нідлз, В.В. Патров, та інші. Проведений аналіз виявив потребу в подальшому досліджені теорії й методології управління товарними операціями в сучасних умовах. Сьогодні, коли зв'язки та інтереси торгівлі перетинаються майже з усіма галузями економіки країни, розробка гнучкого механізму управління процесом формування й використання запасів в торгівлі, їх регулювання, що забезпечує прискорення оборотності оборотних коштів, стає невід'ємною частиною проблеми підвищення ефективності економіки держави в цілому.

Виклад основного матеріалу. Процеси, пов’язані із придбанням товарів, їх зберіганням, рухом та подальшою реалізацією називаються товарними операціями ${ }^{1}$.

Індустрія роздрібної торгівлі знаходиться в постійній динаміці. Сучасні рітейлори постійно адаптують свої стратегії, що передбачає комплексний підхід в організації та управлінні торговельними операціями. Наприклад товари можуть частково виготовлятися на підприємстві, або удосконалюватися, що обумовлює класифікацію такого підприємства як торговельно-виробничого.

Товарні операції, що відбуваються на підприємствах торгівлі, передбачають використання наступних способів їх здійснення:

- стаціонарна реалізація - товарні запаси продаються в спеціалізованих приміщеннях магазинах через посередника - продавця;

- дистанційна стаціонарна торгівля - товари продаються на спеціалізованих, як правило, великих торгівельних площах, де їх покупець самостійно, без продавця, бере товар та розраховується на касі через касира;

- стаціонарна торгівля без візуального представлення товарів - торгівля здійснюється в складських приміщеннях, характеризується виносом товару зі складу та зниженими, порівняно із ринком, цінами продажу;

- інтернет-торгівля - торгівля із використанням віртуальних інтернет-площ для реалізації товарів, що супроводжується виключно візуальною оцінкою товару та його характеристик в описовій формі;

- каталогова торгівля - представлення товарів за допомогою спеціально макетованих каталогів, що використовуються продавцями для забезпечення візуалізації товарів, що пропонуються покупцям;

- торгівля із використанням інструментів автоматизації - товари продаються через спеціальні пристрої - автомати, що не потребує використання послуг продавця та касира.

Варто відзначити, що з розвитком торгівлі постійно змінюються та удосконалюються канали представлення та продажу товару покупцеві. При цьому відбувається постійне зростання кількості об’єктів торгівельної інфраструктури.

Центральним об'єктом товарних операцій виступає товар, який розглядають в якості товарного запасу, якщо він придбавається та зберігається на підприємстві і не пройшов всі стадії підготовки для подальшої реалізації.

Визначення поняття товарів наявне в П(С) БО 9, згідно якого товари - це складовий елемент запасів, представлений у вигляді матеріальних цінностей, що придбані (отримані) та утримуються підприємством з метою подальшого продажу ${ }^{2}$.

Поняття товару виникло із зародженням торгівлі та протягом тривалого періоду іiі розвитку суттєво еволюціонувало в частині розуміння об'єктів, які можуть виконувати роль товарів. Варто відзначити, що твердження, яке наведене в П(С)БО 9 не завжди є вірним, тому що сучасний об'єкт купівлі-продажу може не мати матеріальної форми, що обумовлюється розвитком нових сфер та видів торгівлі. Відповідно, наведення у положенні визначення потребує осучаснення.

Трактуючи поняття товарних запасів, згідно якого запаси не потребують подальшого дороблення та перероблення також не $\epsilon$ цілком вірним. Адже товарні запаси можуть змінюватися на підприємстві з метою підвищення їх якості та рівня цінової пропозиції на нього. Проте в такому

\footnotetext{
${ }^{1}$ Дзюба, О. М. (2016). Товарні операції підприємства: особливості обліку з урахуванням вітчизняного та міжнародного досвіду. Науковий вісник Херсонського державного університету. 17, 1, 134-137.

$<$ http://www.ej.kherson.ua/journal/economic_17/1/37.pdf $>$ (2020, травень, 05).

${ }^{2}$ Положення (стандарт) бухгалтерського обліку, 9 «Запаси», 1999 (Міністерство фінансів України).

Офіиійний сайт Верховної Ради Украӥни <http://zakon.rada.gov.ua/laws/show/z0751-99> (2020, травень, 05).
} 
випадку може виникнути ситуація, коли товари будуть переведені в склад виробничих запасів підприємства. Це зумовлюватиме виникнення на підприємстві виробничої діяльності.

Таким чином, товари, як центральний об'єкт управління товарними операціями можна визначити як сукупність ресурсів. Що мають, або не мають матеріальну форму та придбаваються підприємством з метою їх подальшого перепродажу з, або без дій із їх додаткового опрацювання.

Товари, як об'єкт управління перебувають в процесах постійного руху та проходять різні стадії товарних операцій. Перша стадія стосується виробництва товарів. Процес їх створення відбувається на виробничих підприємствах.

Розроблений готовий продукт підприємства реалізується на ринку за певну винагороду, яка визначається в ціні продукту. У разі придбання його торгівельним підприємством, не з метою споживання, а в цілях подальшої реалізації із використанням різних способів здійснення цього, готовий продукт набуває форми товару.

Товар набуває форми товарного запасу торгівельного підприємства та при придбанні переміщується на складське зберігання ( у випадку, якщо між придбанням та виставленням товару на продаж $\epsilon$ часовий лаг). При настанні періоду реалізації товару по відношенню до нього відбувається внутрішнє переміщення, яке передбачає вилучення товарного запасу із складського господарства в торгівельну мережу.

В торгівельній мережі товар також зберігається із дотриманням належних умов ( в разі потреби кліматичних: дотримання норм вологості, температури повітря; способу розміщення).

Після обрання товару покупцем він реалізується та вибуває із торгівельного підприємства.

У разі проведення торгівлі товаром із використанням інтернет-торгівлі, алгоритм руху товарного запасу дещо змінюється. Після отримання товару на підприємство він фотографується. Інформація про нього розміщується на сайті магазину, а сам товар знаходиться на складському зберіганні.

Після отримання запиту на придбання товару він знімається із складського зберігання та передається по каналу збуту (яким, як правило виступає поштовий посередник) до покупця, таким чином вибуваючи із підприємства. В даному випадку товар не перебуває в торгівельній мережі підприємства торгівлі.

Таким чином, якщо товарний запас проходить через посередника, тобто підприємство торгівлі, його вартість для кінцевого покупця - споживача збільшується на суму націнки, яка формується торгівельним посередником з метою отримання економічної вигоди від здійснюваної діяльності.

Товарні запаси за своїм складом та характеристиками, особливостями зберігання та використання, збуту суттєво відрізняються. 3 метою повноцінного розкриття економічної сутності товарних запасів підприємства торгівлі, для ефективного управління, необхідно здійснити їх класифікацію, що одночасно дозолить суттєво розширити характеристики, які відображають сутність товарних запасів (рис. 1.)

Класифікація товарних запасів за ознакою завезення та зберігання на підприємстві товарів, які потребують попереднього завозу, оскільки виробляються лише протягом певного періоду, а споживаються протягом всього року. Товарні запаси сезонного характеру потребують завезення лише на сезон, коли $€$ активний споживчий ринок. Поточні товарні запаси передбачають постійне поновлення. Товарні запаси спеціалізованого призначення мають цільовий характер та продаються лише окремим видам споживачів (наприклад продукція військово-промислового характеру).

За принципом нормованості, виділення нормованих запасів пов'язане із використанням на підприємстві системи нормування, яка дозволяє мінімізувати надлишкове надходження товарних запасів та зменшити ризики втрат підприємства у зв'язку із недостатністю постачання товарних запасів та невідповідності пропозицій підприємства торгівлі сформованому попиту.

Не нормовані товарні запаси передбачають відсутність єдиного нормативу щодо їх кількості, яка знаходиться на підприємстві. Відсутність нормованості в товарних запасах може супроводжуватися перебоями в їх постачанні. Поряд із тим є товарні запаси, які не потребують суворого нормування, у зв'язку із їх невисокою вартістю. Витрати на нормування таких товарних запасів можуть перевищувати очікуваний ефект від даної процедури, що є економічно невигідним для підприємства.

Розподіл товарних запасів за асортиментом та товари продовольчого та непродовольчого характеру проводиться із урахуванням сутнісних характеристик товарних запасів. Дана класифікація $\epsilon$ досить важливою в макроекономічній статистиці для визначення структури оптового та роздрібного товарообороту. 


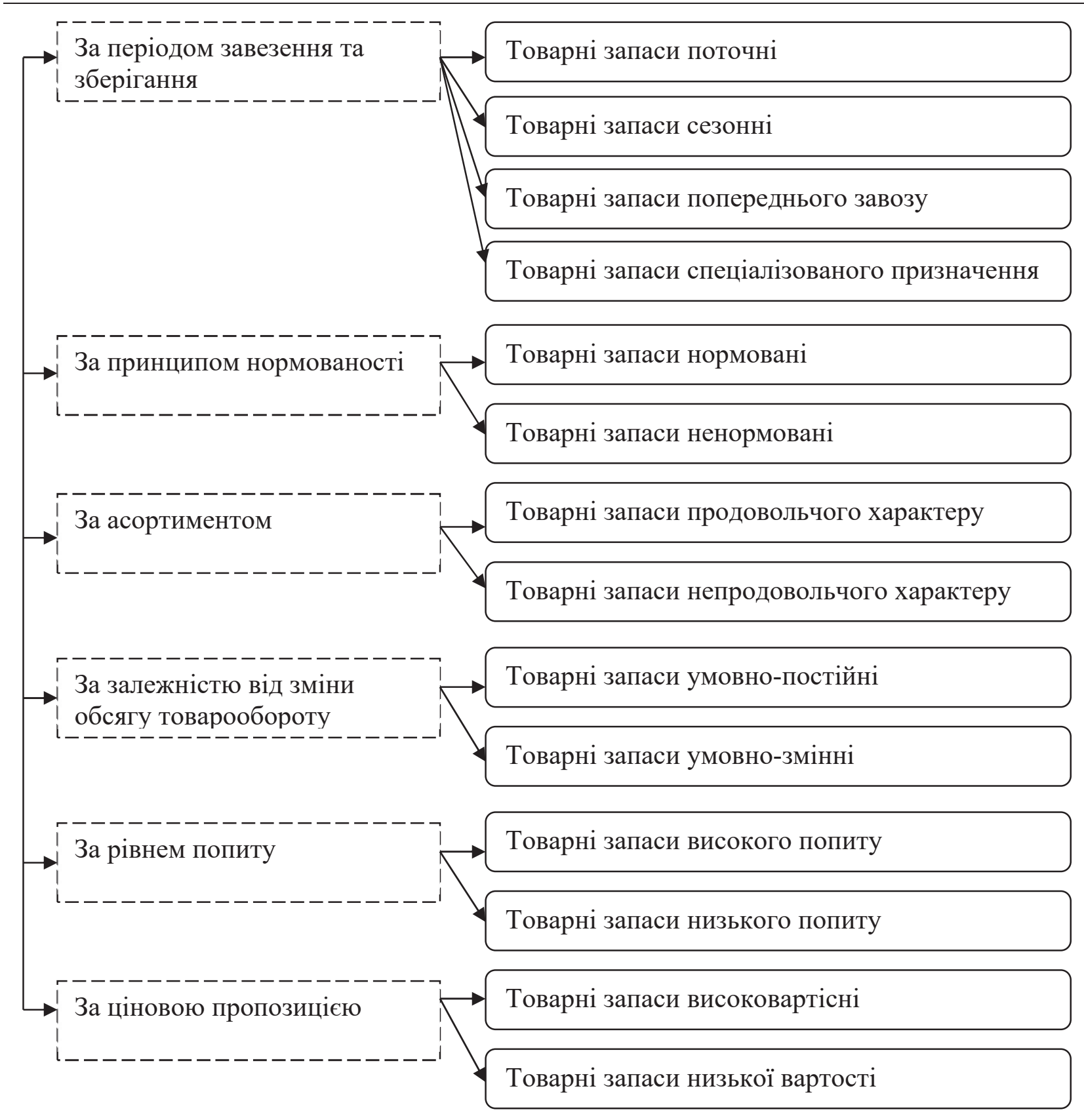

Рис. 1. Класифікація товарних запасів підприємств торгівлі

До товарів продовольчого характеру належать товарні запасі, що використовуються як продукти споживання. Вони характеризуються специфічними властивостями та, в багатьох випадках, потребують спеціалізованого зберігання і $\epsilon$ обмеженими в терміні використання. Товари продовольчого характеру є об'єктом більш прискіпливого та детального контролю, порівняно із другою групою товарів.

Товарні запаси непродовольчого характеру не передбачають їх одноразового споживання, а можуть використовуватися в побуті неодноразово. Вони характеризуються відсутністю спеціальних вимог до кліматичних умов їх зберігання (у більшості випадків) та використанням механізму гарантування придатності та ефективної роботи товару протягом певного періоду.

В складі непродовольчих товарів окремо варто виділити фармацевтичні препарати. Вони формують спеціалізовану групу непродовольчих товарів. Їх характеристики передбачають використання спеціальних умов зберігання, що зумовлено відповідними фармацевтичними та медичними нормами, а також спеціалізованими якостями окремих видів медичних препаратів. 
На фармацевтичні препарати не поширюється механізм гарантування. У випадку втрати препаратом актуальності для споживача він не може бути повернений в збутову мережу.

В залежності від зміни обсягу товарообороту товарні запаси можна поділити на умовнопостійні та умовно-змінні. Перша група товарів не змінюється протягом релевантного періоду при зміні обсягів товарообороту, що обумовлюється стабільністю попиту на товари, або зміною їх вартісної пропозиції, яка супроводжується відсутністю зниження попиту.

Умовно-змінні товарні запаси - це такі товари, які знаходяться у прямій залежності та в тісній кореляції із обсягами товарообороту підприємства. При потребі збільшення обсягу реалізації на підприємствах торгівлі роблять акцент саме на дані види товарних запасів. При цьому варто відзначити, що споживчий ринок щодо таких товарів має бути гнучким та спроможним поглинути збільшену кількість товарної пропозиції. Останнє може бути характерним для товарів першої необхідності, а бо для умов, що характеризуються виходом на нові споживчі ринки та ніші.

За рівнем попиту товарні запаси можна класифікувати на товари високого попиту, що характеризуються постійною потребою у покупців, або знаходяться на етапі введення на ринок, що викликає зацікавленість споживачів у них. Як правило, інноваційні продукти характеризуються високим попитом. Проте із розвитком сучасного автоматизованого суспільства тривалість такого високого попиту поступово скорочується.

До товарів низького попиту відносяться товарні запаси, які знаходяться на кінцевому етапі свого життєвого циклу. Також до них можуть відноситися дороговартісні товарні запаси та товари не першої потреби.

Варто відзначити, що розподіл товарних запасів, на такі, що характеризуються високим попитом, та такі, що мають низький рівень попиту є досить умовним та залежить від рівня платоспроможності населення.

Розподіл товарних запасів за класифікаційною ознакою залежності від попиту також можна здійснити на такі групи як товари стабільного попиту - це товарні запаси, що належать до групи першої необхідності та товари нестабільного попиту, потреба яких у споживачів знаходиться у тісній прямій залежності від рівня реальних доходів.

За ознакою цінової пропозиції товарні запаси можна поділити на дорого-вартісні та товарні запаси, що характеризуються низькою вартістю. Чим вищої вартості $є$ товарний запас, тим більшу націнку на нього робить торгівельне підприємство, що супроводжується подальшим зростанням ціни такого товарного продукту.

Варто відзначити, що формувати високі показники доходів від реалізації товарів можна як на основі продажу дорого-вартісних, так і шляхом продажу дешевих товарів. В даному випадку визначальними факторами виступають обрана підприємством маркетингова політика, система позиціонування продукції, сформована збутова мережа, політика після продажного обслуговування, система гнучких знижок та акційна політика, аукціонні та ярмаркові продажі, рекламна політика підприємства тощо. аспекти:

В системі управління товарними операціями підприємства вагоме значення мають наступні

- виважений та обгрунтований підхід до обрання постачальника товарних запасів, визначення каналів отримання товарів на підприємство, формування ефективної системи закупівельних цін;

- забезпечення ритмічності та рівномірності поставок товарних запасів на підприємство;

- визначення та економіко-аналітичне обгрунтування системи нормування товарних запасів;

- встановлення методик формування націнки на товарні запаси, що передаються на реалізацію;

- визначення системи побудови збутової мережі підприємства;

- обрання способів позиціонування та рекламування підприємства та продукції, що реалізується підприємством;

- визначення політики після продажного обслуговування, якщо така може мати місце, враховуючи різновидність та структуру асортименту продукції.

Управління товарними операціями проводиться з метою забезпечення синхронності роботи підприємства сфери торгівлі, покриття витрат на придбання товарних запасів та формування належного рівня рентабельності товарообігу підприємства. Управління товарними операціями $€$ однією із складових системи управління підприємством. Важливим елементами управлінської політики є визначення методів оцінки вибуття товарних запасів із підприємства та формування 
методики і встановлення розміру націнки на підприємстві. Саме від останньої залежить рівень рентабельності підприємства.

На нашу думку, щодо управління важливими аспектами, що забезпечують стабільність та ефективність торговельної діяльності є наступне:

1. Із зростанням обсягів товарних запасів необхідно посилити контроль за їх класифікацією, ассортиментом та чітким розподілом на всіх етапах - від придбання до передачі споживачеві.

2. Застосовуючі декілька каналів продажу (магазин, інтернет- як особистий сайт, так i різноманітні мережі, на замовлення, тощо) - рівень відслідковування руху товарних запасів повинен бути автоматизованим і відповідати якісному оперативному контролю.

3. Повний та точний контроль - як засіб ефективного управління, дасть можливість регулювання товарними запасами на предмет своєчасного надходження товарів, що користуються попитом та зменшення обсягів непопулярних товарів.

4. Наявність системи відстежування руху товарів: продаж, обмін, повернення, особливо через декілька каналів реалізації, дасть можливість швидко та ефективно проводити миттєві перевірки наявності товарних запасів, з метою виявлення залишків, зникнення, пересортиці та ін.

5. Наявність ефективної системи управління, забезпечує попит споживачів швидко і якісно, спонукає до подальшої співпраці, що сприяє зростанню доходів підприємства.

Запаси - це поняття, що характеризується нагромадженням певних об' єктів. В даному випадку не так яскраво виділяється факт необхідності їх переробки або доопрацювання, що є більш характерним для товарів. Тому, вважаємо за доцільне використовувати поряд із поняттям товару такий синонім як товарний запас. На користь такого трактування також виступає облікова система, яка передбачає врахування товарів у склад запасів підприємства (згідно плану рахунків) ${ }^{1}$

Товарні запаси, як об'єкт управління торговельного підприємства, виконують певні функції: забезпечують безперервність розширеного виробництва й обігу, в процесі яких відбуваються їхнє систематичне утворення і витрачання; задовольняють платоспроможний попит населення, оскільки $€$ формою товарної пропозиції; характеризують співвідношення між обсягом та структурою попиту і товарної пропозиції. При цьому підприємство, як правило, не вносить суттєвих змін у фізичну форму товарних запасів, вже при придбанні вони $є$ готовою продукцією.

Висновки. Таким чином, товарні операції $€$ важливим господарським елементом, що забезпечує здійснення торговельної діяльності та реалізуються підприємствами торгівлі відповідно до визначеного алгоритму дій, що відповідає стратегії управління товарними ресурсами. Центральним об'єктом товарних операцій витупають товарні запаси, сутнісні характеристики яких визначаються в залежності від класифікаційних груп, до яких їх можна віднести. Саме товарні запаси забезпечують безперервність товарних операцій на підприємстві.

\section{References:}

1. Dziuba, O. M. (2016). Tovarni operatsii pidpryiemstva: osoblyvosti obliku z urakhuvanniam vitchyznianoho ta mizhnarodnoho dosvidu [Commodity operations of the enterprise: peculiarities of accounting taking into account domestic and international experience]. Naukovyi visnyk Khersonskoho derzhavnoho universytetu [Scientific Bulletin of Kherson State University], 17, 1, 134-137.

$<$ http://www.ej.kherson.ua/journal/economic_17/1/37.pdf> (2020, May, 05). [in Ukrainian].

2. Polozhennia (standart) bukhhalterskoho obliku 9 «Zapasy», 1999 (Ministerstvo Finansiv Ukrainy) [Accounting Standard (Standard) 9 «Inventories», 1999]. Ofitsiynyy sayt Verkhovnoyi Rady Ukrayiny [Official website of the Verkhovna Rada of Ukraine]. <http://zakon.rada.gov.ua/laws/show/z0751-99> (2020, May, 05).

[in Ukrainian].

3. Olinichenko, K.S. (2017). Upravlinnia tovarnymy zapasamy pidpryiemstv rozdribnoi torhivli : monohrafiia [Retail inventory management : monograph]. Kharkiv: Ivanchenko I.S. [in Ukrainian].

\footnotetext{
${ }^{1}$ Олініченко, К.С. (2017) Управління товарними запасами підприємств роздрібної торгівлі : монографія. Харків: видавництво Іванченка І.С.
} 